\title{
What is in? Pneumoperitoneum after sexual intercourse
}

\author{
Patricia Botelho, ${ }^{1}$ Ana Franky Carvalho, ${ }^{1,2}$ Helena Torrão, ${ }^{3}$ Pedro Leão ${ }^{1,2}$
}

${ }^{1}$ Department of General Surgery, Hospital of Braga, Braga, Portugal

${ }^{2}$ School of Health Sciences, University of Minho, Braga, Portugal

${ }^{3}$ Department of Radiology, Hospital of Braga, Braga, Portugal

\section{Correspondence to} Dr Patricia Botelho, pscfb@yahoo.com
To cite: Botelho $\mathrm{P}$ Carvalho AF, Torrão $\mathrm{H}$, et al. BMJ Case Rep Published online: [please include Day Month Year] doi:10.1136/ bcr-2013-009667

\section{DESCRIPTION}

A 49-year-old woman presented to the emergency department with severe abdominal pain after vigorous sexual intercourse. The patient had a history of hysterectomy (due to cervix carcinoma) 3 months before and due to postoperative haematic losses, the patient frequently used tampons. The patient claimed she had a tampon within the abdominal cavity after sexual intercourse. An initial gynaecological examination showed no evidence of vagina vault damage and foreign body. Since abdominal pain persisted, the patient was submitted to an abdominal-pelvic CT scan that revealed a pneumoperitoneum and the presence of a foreign body in the abdominal cavity (arrow in figure 1A). The patient underwent minilaparotomy, and a tampon was found among intestine ansae (figure 1B); this occurred due to the total rupture of the vaginal vault, which was repaired through colporrhaphy. There were no significant events in the postoperative period. This case serves to highlight the relevance of patient self-report, sometimes so underestimated by clinicians and presents for the first time in literature the CT imaging of a tampon in the abdominal cavity.

\section{Learning points}

- Do not neglect patient self-report.

- Investigate patient's history.

- Always suspect a persistent abdominal pain.

Contributors PB evaluated the patient and wrote the manuscript. AFC and PL were involved in drafting the manuscript and revising it critically for important intellectual content. PB and PL performed the surgery. HT was involved in CT scanning and imaging evaluation.

\section{Competing interests None.}

Patient consent Obtained.

Provenance and peer review Not commissioned; externally peer reviewed.
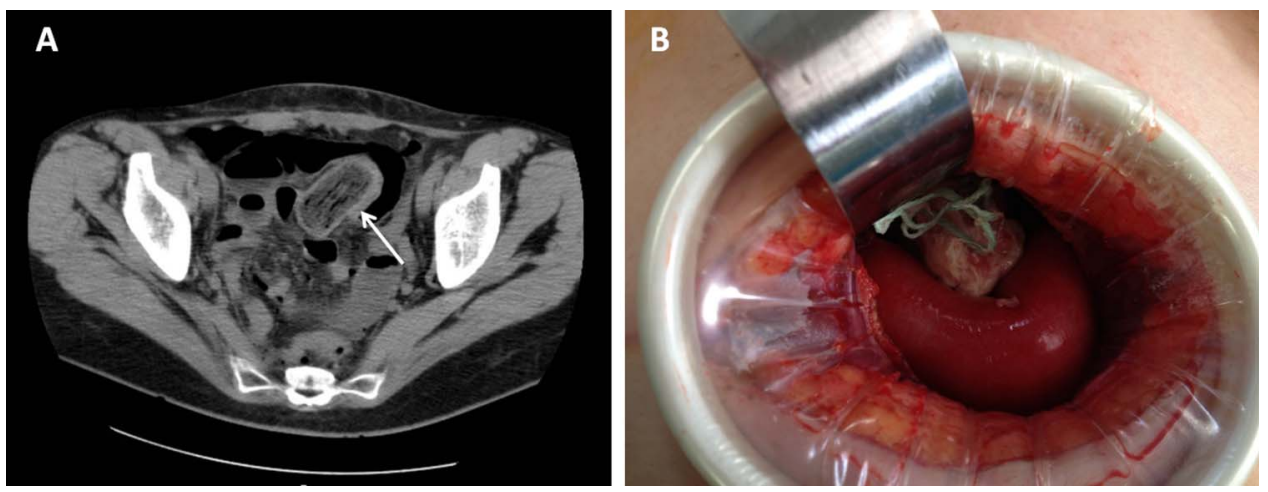

Figure 1 (A) CT scan demonstrating the tampon body in the abdominal cavity. (B) In situ tampon during minilaparotomy.

Copyright 2013 BMJ Publishing Group. All rights reserved. For permission to reuse any of this content visit http://group.bmi.com/group/rights-licensing/permissions.

BMJ Case Report Fellows may re-use this article for personal use and teaching without any further permission.

Become a Fellow of BMJ Case Reports today and you can:

- Submit as many cases as you like

- Enjoy fast sympathetic peer review and rapid publication of accepted articles

- Access all the published articles

- Re-use any of the published material for personal use and teaching without further permission

For information on Institutional Fellowships contact consortiasales@bmjgroup.com

Visit casereports.bmj.com for more articles like this and to become a Fellow 